\title{
Phosphate Solidification Of Caustic Process Solution Waste
}

\author{
Dean A. Puryear \\ J. Steve Buckingham \\ Milton H. Campbell
}

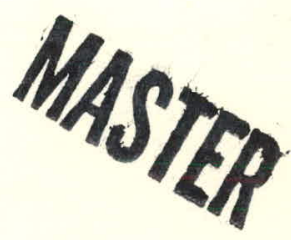

May 1972

Atlantic Richfield Hanford Company Richland, Washington 99352 


\section{DISCLAIMER}

This report was prepared as an account of work sponsored by an agency of the United States Government. Neither the United States Government nor any agency Thereof, nor any of their employees, makes any warranty, express or implied, or assumes any legal liability or responsibility for the accuracy, completeness, or usefulness of any information, apparatus, product, or process disclosed, or represents that its use would not infringe privately owned rights. Reference herein to any specific commercial product, process, or service by trade name, trademark, manufacturer, or otherwise does not necessarily constitute or imply its endorsement, recommendation, or favoring by the United States Government or any agency thereof. The views and opinions of authors expressed herein do not necessarily state or reflect those of the United States Government or any agency thereof. 


\section{DISCLAIMER}

Portions of this document may be illegible in electronic image products. Images are produced from the best available original document. 


\title{
ARH-SA-120 \\ Conf. $720628-2$
}

\section{PHOSPHATE SOLIDIFICATION \\ OF CAUSTIC PROCESS SOLUTION WASTE}

\author{
By \\ Dean A. Puryear \\ J. Steve Buckingham \\ Milton H. Campbell \\ Separations Chemistry Laboratory \\ Research and Development \\ Chemical Processing Division
}

May 1972

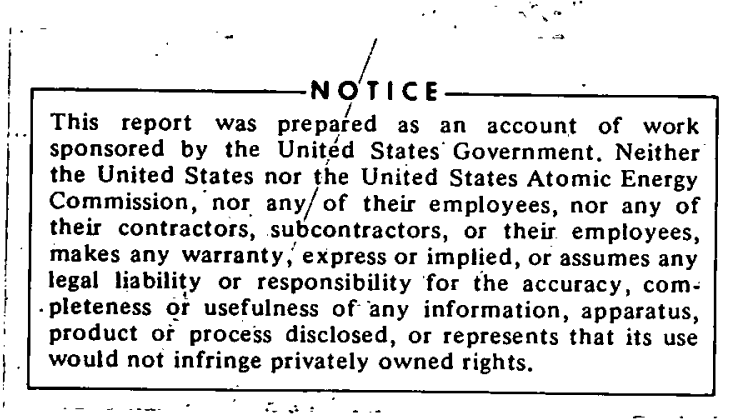

\section{ATLANTIC RICHFIELD HANFORD COMPANY}

RICHLAND, WASHINGTON

To be presented at the

American Chemical society NW Regional Meeting

Corvalis, Oregon

June $15-16,1972$

Operated for the Atomic Energy Commission by

Atlantic Richfield Hanford Company under Contract \#AT(45-1)-2130 


\begin{abstract}
A process for solidifying concentrated high-salt process solution waste with phosphoric acid is investigated on a laboratory-scale. Discussion of the proposed application of this process is presented, as well as the tests and results used to establish the parameters for solidification candidates. Synthetio high-salt caustic wastes are used to accumulate data on the kinetics of the reaction. The product is postulated to be the chemical complex

$$
7\left(\mathrm{Na}_{3} \mathrm{PO}_{4} \cdot 12 \mathrm{H}_{2} \mathrm{O}\right) \mathrm{NaOH}
$$

or a derivative thereof. Quality of the product is directly related to wt\% water, total sodium molarity, and the amount of monovalent sodium salt present in the waste candidate.
\end{abstract}




\section{TABLE OF CONTENTS}

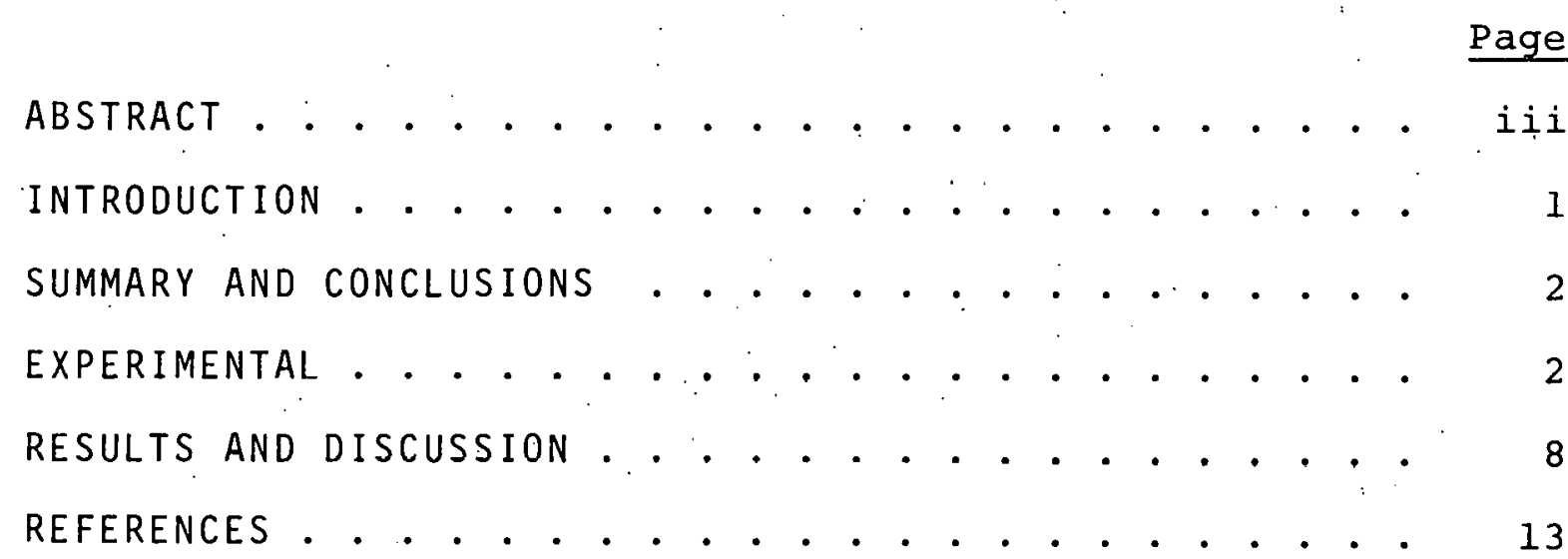




\section{PHOSPHATE SOLIDIIFICATION \\ OF CAUSTIC PROCESS SOLUTION WASTE}

\section{INTRODUCTION}

The Atlantic Richfield Hanford Company as a prime contractor for the Atomic Energy Commission has long been concerned with the responsibility for effective control of radioactive waste solutions generated in the reprocessing of nuclear fuel elements. Our experiences in the control and disposal of these wastes are of general interest as the use of nuclear reactors increases [1] to supply the necessary power for modern communities and industry.

Efforts toward effective control and disposal of quantities of waste from reprocessing fuel elements has resulted in a variety of different concepts and practices. At Hanford these wastes were stored in underground, concrete tanks lined with mild steel. To prevent corrosion of the mild steel liners, acid waste solutions were converted to caustic waste ( $\mathrm{pH} 8$ or greater) with sodium hydroxide prior to storage.

In 1964 with the implementation of the In-Tank Solidification (ITS) program, efforts were directed toward containing the wastes in an immobile salt of reduced volume. In simple concept, ITS boils off the water and leaves the tanks filled with a cake of solid salt, thus reducing the volume of waste and creating an immobile waste-form for storage.

However processing experience has indicated that as concentration of these waste proceeds, the bottom cooling tanks behave as a large fractional crystallizer. This results in 
the recycled mother liquor becoming enriched with the more soluble compounds--namely, sodium hydroxide, sodium nitrate, and sodium aluminate. Because of inherent limitations in thermodynamics, boil-off rates and bottoms concentration in the evaporator system decreased rapidly as the caustic level increased. When operation limits were reached, the tanks contained a mother liquor or concentrated bottoms, and salt cake with interstitial bottoms concentrate. [2]

\section{SUMMARY AND CONCLUSIONS}

The addition of phosphoric acid to concentrated high-salt caustic waste produces complex trisodium orthophosphate hydrate. The reaction occurs at a sodium-to-phosphate mole ratio of $3.12: 1$ of the available sodium, that associated with. $\mathrm{OH}^{-}$or $\mathrm{AlO}_{2}{ }^{-}$. The amount of water present in the solidification feed must be no greater than 7 to 8 wt: excess of water of hydration when the stoichiometric amount of phosphoric acid is reacted with the available sodium. A smaller percentage of water is retained in solids derived from low caustic-high monobasic salt concentrations.

\section{EXPERIMENTAL}

The mobility of concentrated bottoms liquid in the tanks is very undesirable. While techniques for the removal of this liquid are being developed, the solidification of these concentrated liquid wastes is the current and real problem. Proposed methods of solidifying concentrated bottoms include the following:

- Cooling.

- Additional evaporation. 
- Acid neutralization/re-evaporation.

- Solidification by chemical addition.

In this report the solidification by a minimal chemical addition is considered.

Essentially, concentrated bottoms liquor contains sodium. compounds of aluminate, hydroxide, nitrate, and nitrite. The amounts of each constituent in Tank 103-BY are shown in Table I. Laboratory tests indicate that neutralizationreconcentration using different mineral acids and acid salts results in very little gain in total volume reduction, about $30 \%$ solidification, and slightly improved thermodynamics with the most efficient mineral acid. [3] However, during the testing of mineral acids for neutralization/reconcentration, the discovery that the addition of phosphoric acid to a concentrated waste (Figure 1) produces significant quantities of solids presents a new concept of terminal bottom concentrated solidification.

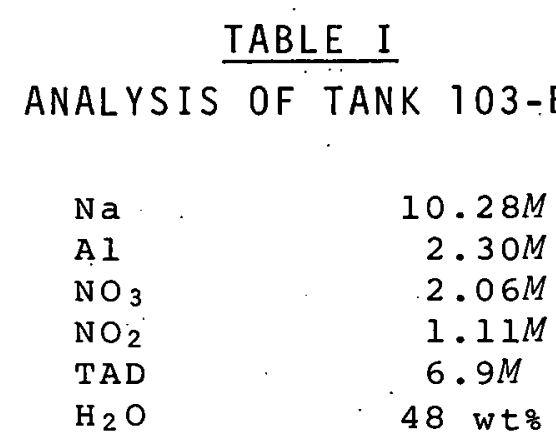

In early experiments the observation that different synthetic wastes produce varying degrees of solidification was assumed to be a function of the individual chemical composition of each synthetic. However, chemical analysis of the solids shows the same composition as the concentrated bottoms with the addition of phosphate. There is an indication, 


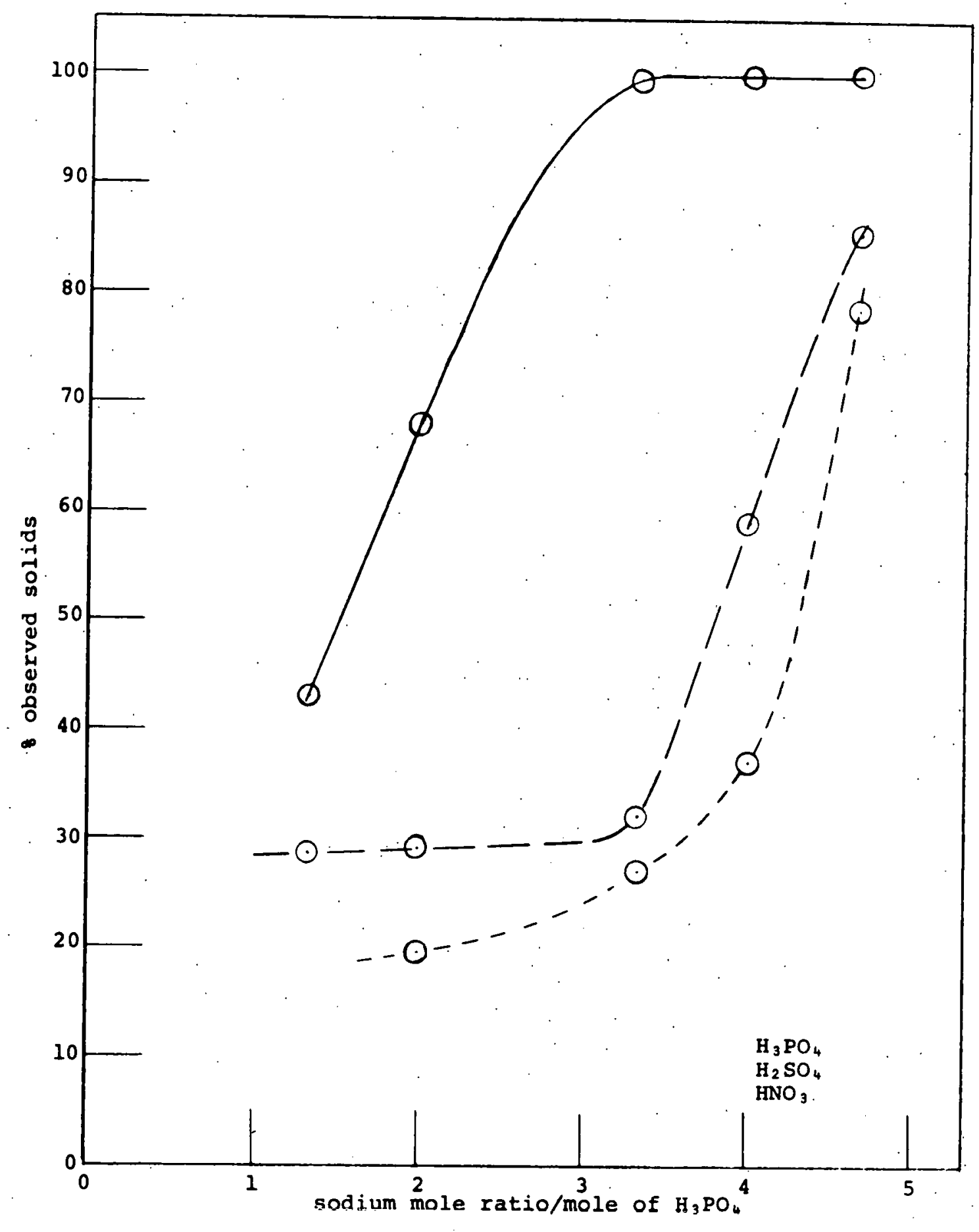

FIGURE 1

SOLIDS PRODUCED BY THE ADDITION OF DIFFERENT MINERAL

ACIDS TO A SYNTHETIC CAUSTIC HIGH-SALT WASTE 
as shown in Table II, that during the addition of phosphoric acid the sodium concentration in the liquid phase decreases significantly before the aluminum precipitates.

TABLE I I

ANALYSIS OF A SECOND STAGE WASTE EVAPORATION DURING NEUTRALIZATION BY PHOSPHATE SOLIDIFICATION

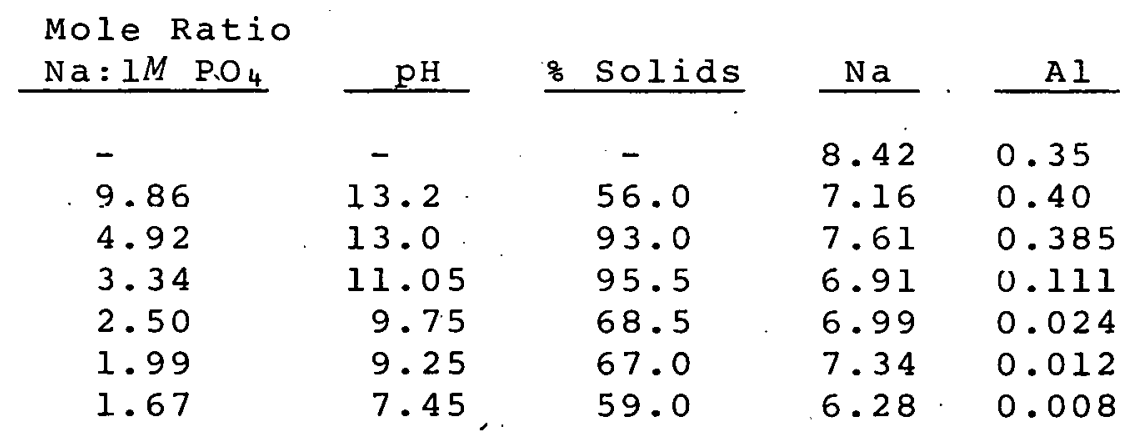

Solidification curves of extremely high caustic sodium salt waste as used in Figure 1 show that total solidification has a direct relationship on the amount of phosphoric acid added. Later solidification curves (Figure 2) of lowcaustic, high-salt waste indicate that there is a definite sodium-to-phosphate mole ratio of $3: 1$ i.f it is assumed that monovalent sodium salts do not react with the phosphate in an alkaline media.

Microscopic studies. of the crystals are used primarily to determine the size of crystalline product. However, the two micrographs in Figure 3 show the structure to be octagonal crystals. X-Ray diffraction patterns confirm the presence of a hydrated phosphate and show strong diffraction patterns of sodium nitrate.

Water analyses of the salt cake vary from 52.4 to $55.8 \mathrm{wt} \%$ (Table III) indicating that the amount of water in the salt cake corresponds closely in range to the waters of hydration of $\mathrm{H}_{3} \mathrm{PO}_{4} \cdot 10 \mathrm{H}_{2} \mathrm{O}$ and $\mathrm{H}_{3} \mathrm{PO}_{4} \cdot 12 \mathrm{H}_{2} \mathrm{O}$. 


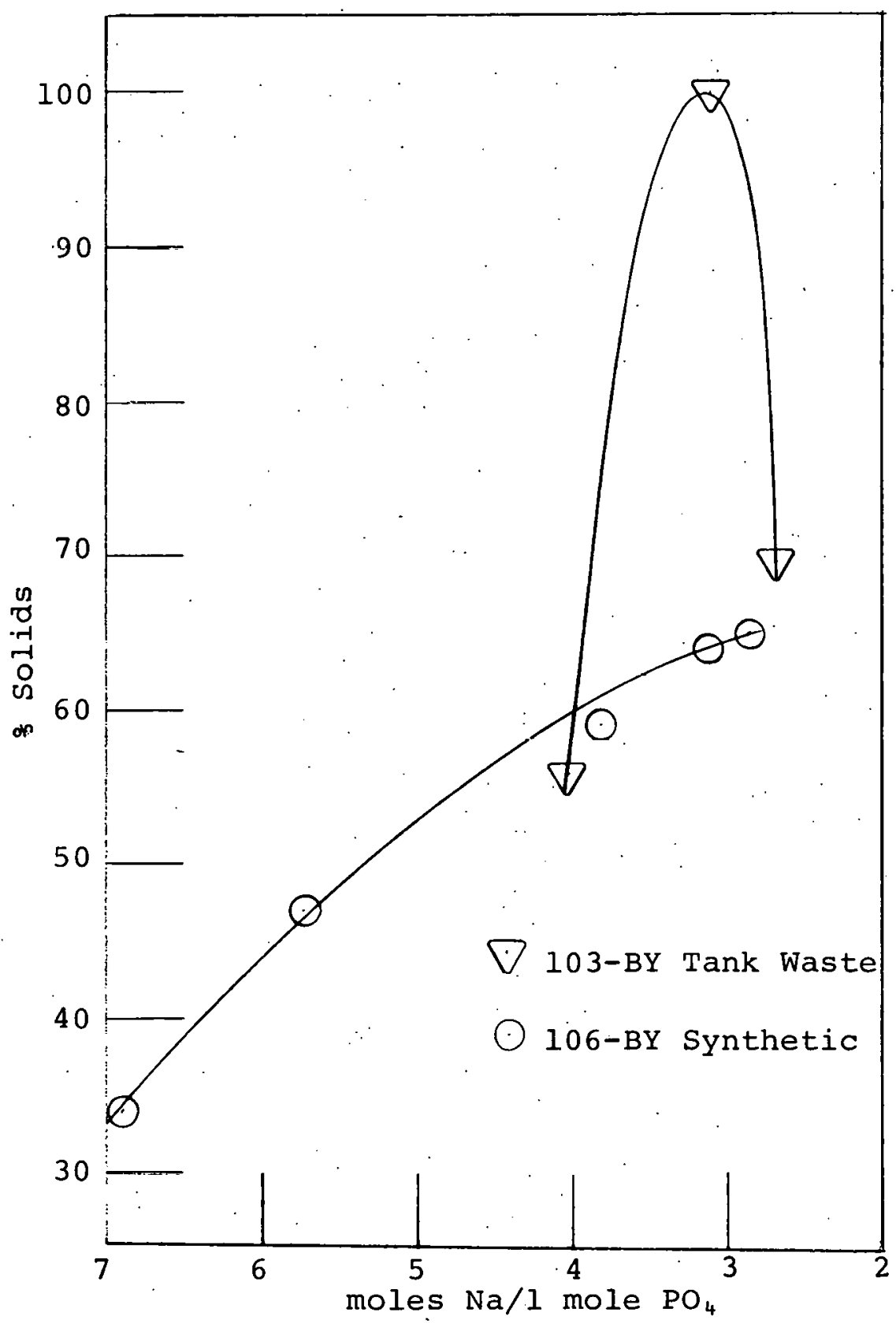

FIGURE 2

SOLIDIFICATION CURVES OF WASTE SHOWING THAT MAXIMUM SOLIDS OCCUR AT A SODIUM-TO-PHOSPHATE MOLE RATIO OF $3.12: 1$ 

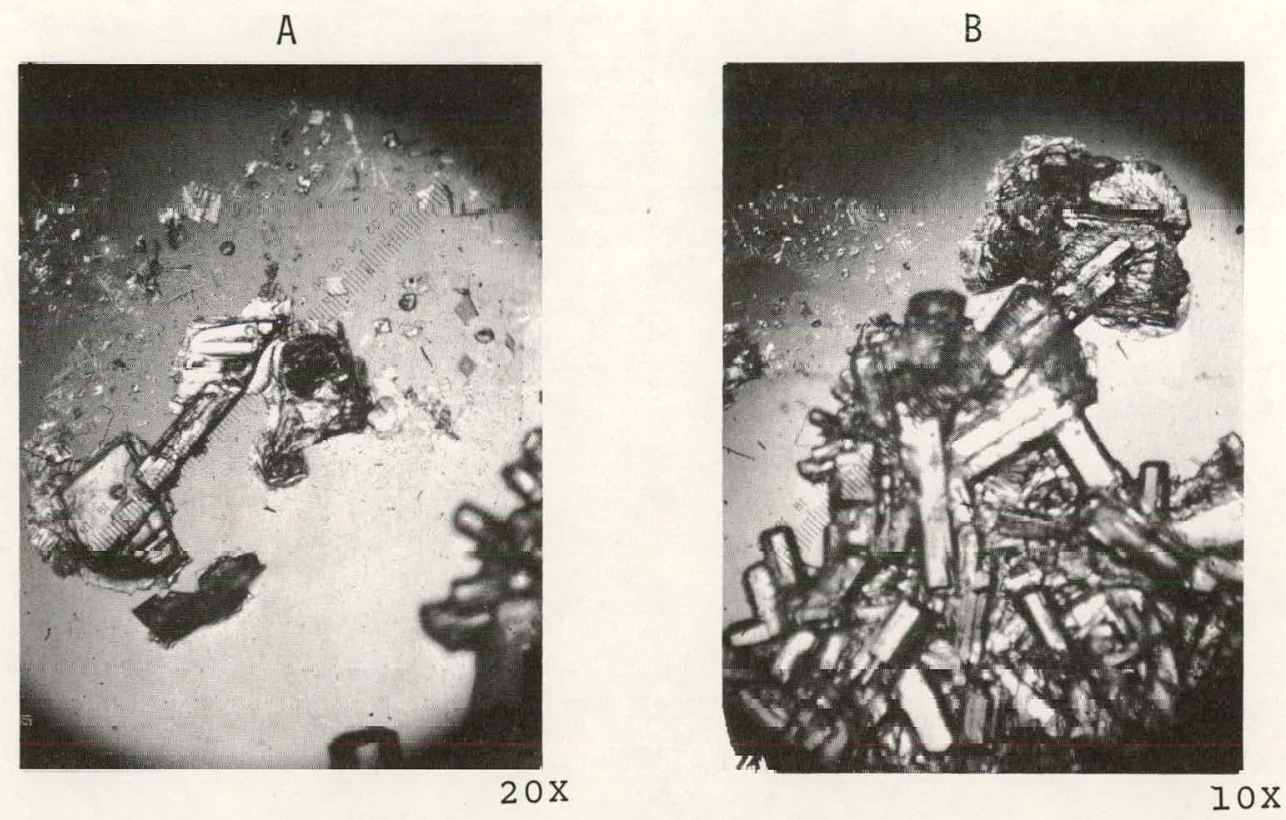

\section{FIGURE 3}

PHOTOMICROGRAPHS OF SOLIDIFIED SYNTHETIC WASTE SHOWING RANGE IN CRYSTAL SIZE AND SHAPE

[ $B$ is enlargement of central left portion of $A$ ]

\section{TABLE I I I}

Wt $\% \mathrm{H}_{2} \mathrm{O}$ OF DIFFERENT SOLIDIFIED SYNTHETIC WASTES DETERMINED BY WEIGHT LOSS WHEN IGNITED TO $110{ }^{\circ} \mathrm{C}$

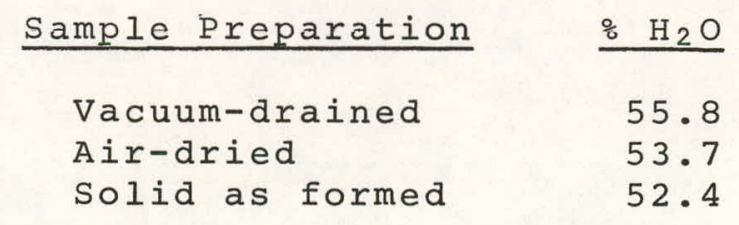


Thermogravimetric Analysis (TGA) and Differential Thermal Analysis (DTA), Figure 4, confirm the water content of the solids and show that the waters of hydration release at $100{ }^{\circ} \mathrm{C}$, again correlating closely to sodium orthosphosphate.

To assess the effect of $\mathrm{H}_{2} \mathrm{O}$ on solidification by phosphate addition, a 106-BY synthetic (Table IV) with a total sodium molarity of 8.1 and a water content of 61.3 wto is used to make up three other solutions by dilution and evaporation.

\begin{tabular}{|c|c|c|}
\hline TABLE & IV & \\
\hline COMPOSITION & $O F$ & $106-B Y$ \\
\hline $\mathrm{NaAlO}_{2}$ & & $2 . M$ \\
\hline $\mathrm{NaNO}_{2}$ & & $1 . M$ \\
\hline $\mathrm{NaNO}_{3}$ & & $2 . M$ \\
\hline $\mathrm{NaOH}$ & & $3.1 M$ \\
\hline
\end{tabular}

Volume percent solids are determined on each adjusted feed with selected mole ratios of sodium-to-phosphate. Interstitial liquids are removed by pressing the cooled mixture under 28 psi of static pressure. Figure 5 shows that total solidification does not occur in the wastes containing greater than $60 \mathrm{wt} \% \mathrm{H}_{2} \mathrm{O}$. The wastes containing 50 wt: $\mathrm{H}_{2} \mathrm{O}$ or less demonstrate complete solidification under the conditions tested.

\section{RESULTS AND DISCUSSION}

From the experiments above we discern (1) that solids are produced on a sodium-to-phosphate mole ratio of $3: 1$; and (2) that total solidification is a function of the wto $\mathrm{H}_{2} \mathrm{O}$ in the waste. In a scholarly work, Beîl[4] states that trisodium phosphate compounds containing more than $8 \mathrm{H}_{2} \mathrm{O}$ are not simple hydrates, but hydrated complexes 


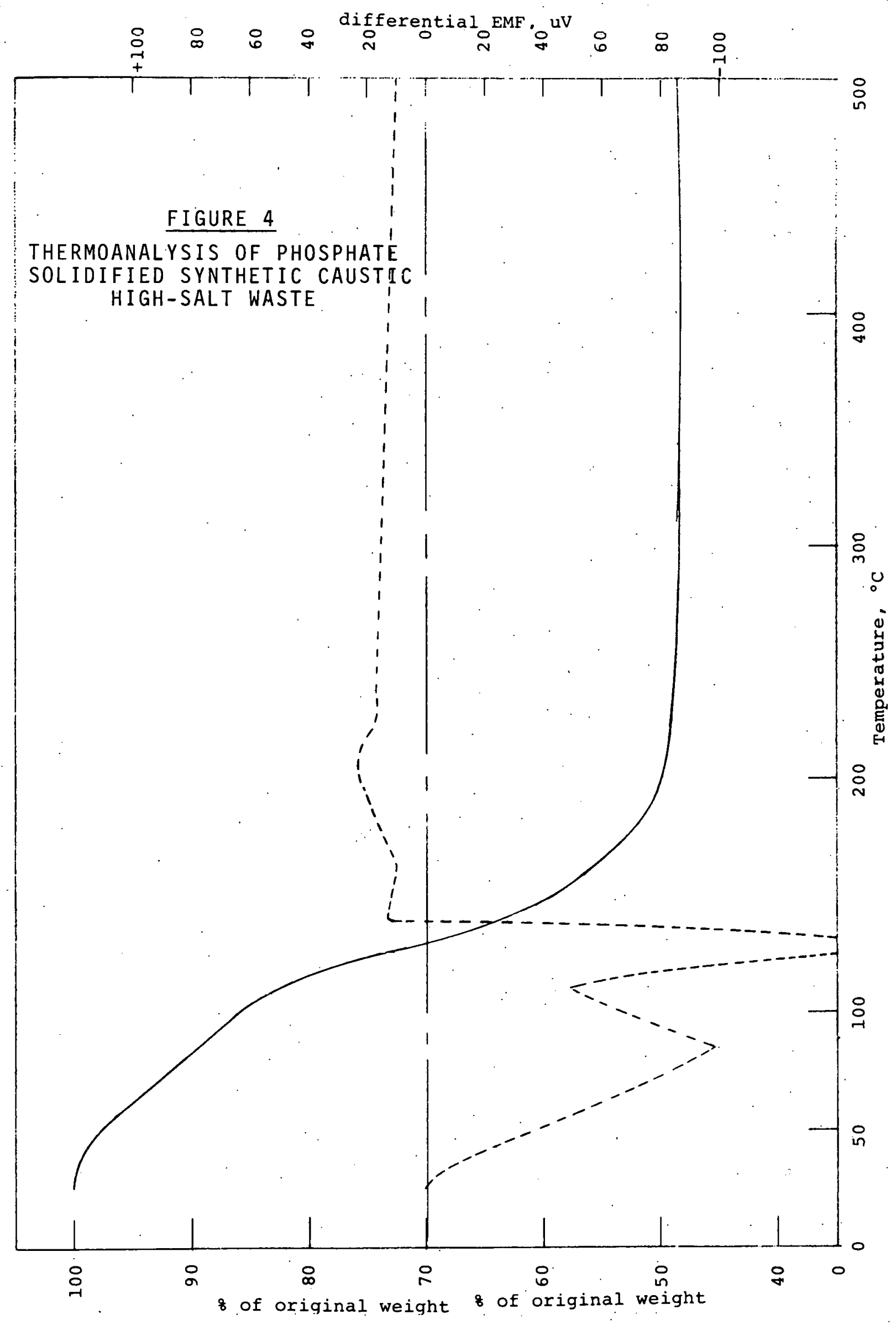




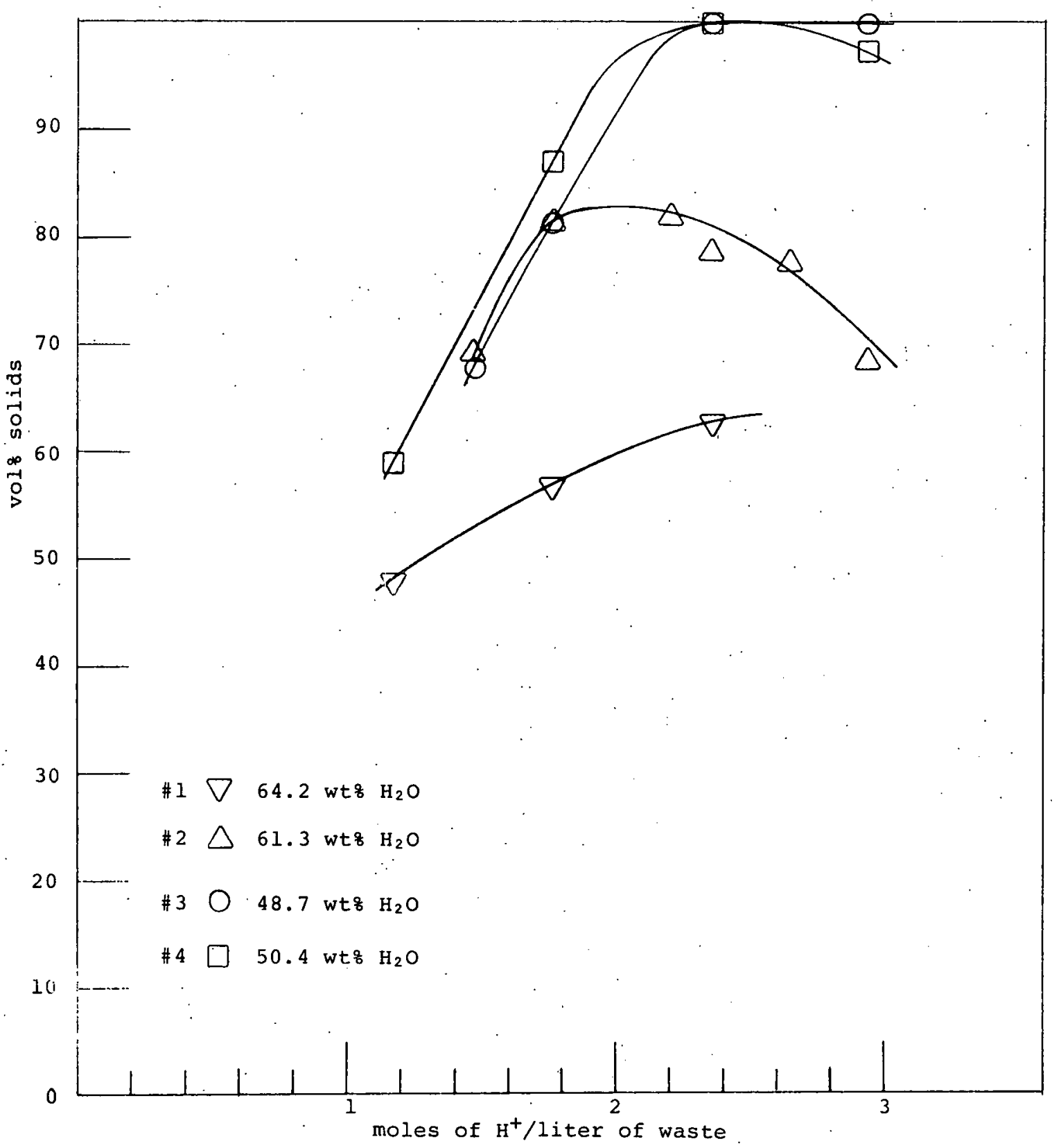

FIGURE 5

SOLIDIFICATION OF DIFFERENT $\mathrm{H}_{2} \mathrm{O}$

CONTENT 106-BY SYNTHETICS 
which always contain the sodium salt of a monobasic acid or sodium hydroxide. These complexes are of two types and can be represented by the following formulas:

$$
\mathrm{nNa}_{3} \mathrm{PO}_{4} \cdot \mathrm{NaY} \cdot \mathrm{XH}_{2} \mathrm{O}
$$

where $\mathrm{N}=1$ or $2, \mathrm{Y}$ is a monobasic anion, and $\mathrm{X}=18$ or 19 and

$$
\mathrm{n}\left(\mathrm{Na}_{3} \mathrm{PO}_{4} \cdot \mathrm{XH}_{2} \mathrm{O}\right) \mathrm{NaY}
$$

where $\mathrm{N}=4$ to $7, \mathrm{X}=11$ or 12 , and $\mathrm{Y}$ is a monobasic anion $\mathrm{OH}, \mathrm{NO}_{2}, \mathrm{NO}_{3}$, or $\mathrm{AlO}_{3}$. Later work by Wendrow and Kobe[5] shows a sodium-to-phosphate mole ratio of 3.21 when $\mathrm{N}=5$ and 3.12 when $N=7$ in formula (2).

Considering the composition of synthetic 106-BY in Table IV or the actual waste analysis in Table $I$ as it might apply to formula (2), the following hydrated complexes of trisodium orthophosphate may be present:

Complex
$5\left(\mathrm{Na}_{3} \mathrm{PO}_{4} \cdot 12 \mathrm{H}_{2} \mathrm{O}\right) \mathrm{NaOH}$
$7\left(\mathrm{Na}_{3} \mathrm{PO}_{4} \cdot 12 \mathrm{H}_{2} \mathrm{O}\right) \mathrm{NaOH}$
$4\left(\mathrm{Na}_{3} \mathrm{PO}_{4} \cdot 11 \mathrm{H}_{2} \mathrm{O}\right) \mathrm{NaNO}_{2}$
$7\left(\mathrm{Na}_{3} \mathrm{PO}_{4} \cdot 12 \mathrm{H}_{2} \mathrm{O}\right) \mathrm{NaNO}_{3}$
$7\left(\mathrm{Na}_{3} \mathrm{PO}_{4} \cdot 12 \mathrm{H}_{2} \mathrm{O}\right) \mathrm{NaNO}_{3}$
$7\left(\mathrm{Na}_{3} \mathrm{PO}_{4} \cdot 12 \mathrm{H}_{2} \mathrm{O}\right) \mathrm{NaAlO}_{2}$

Melting Point

${ }^{\circ} \mathrm{C}$

74

70

72

60

$7\left(\mathrm{Na}_{3} \mathrm{PO}_{4} \cdot 12 \mathrm{H}_{2} \mathrm{O}\right) \mathrm{NaNO}_{3}$

Relating the information above to solidification of caustic salt waste, we would expect the following reaction:

When phosphoric acid is first added, it reacts primarily with the free caustic, forming trisodium orthophosphate. The heat of reaction raises the temperature of the slurry to approximately $90{ }^{\circ} \mathrm{C}$. At this temperature the trisodium phosphate is present as the hexa- or octahydrates. In addition, some local precipitation of $A l(O H)_{3}$ occurs. As the slurry cools, the 
complex hydrates form, taking on additional waters of hydration. The loss of water into the complex hydrates results in a solution supersaturated with $\mathrm{NaNO}_{3}, \mathrm{NaNO}_{2}$, and $\mathrm{NaAiO}_{2}$ which also begin to crystallize.

Solidification by phosphate addition is dependent on the amount of water present in the bottoms concentrate. The solidification of a solution containing total reactable sodium can be expressed by the formula

$$
22 \mathrm{NaOH} 56.28 \mathrm{H}_{2} \mathrm{O}+7\left(\mathrm{H}_{3} \mathrm{PO}_{4} 0.96 \mathrm{H}_{2} \mathrm{O}\right) \rightarrow\left(7 \mathrm{Na}_{3} \mathrm{PO}_{4} 12 \mathrm{H}_{2} \mathrm{O}\right) \mathrm{NaOH}
$$

The formula for $8.58 \mathrm{H}_{3} \mathrm{PO}_{4}$ is shown as $\left(\mathrm{H}_{3} \mathrm{PO}_{4} 0.96 \mathrm{H}_{2} \mathrm{O}\right)$. In this formula the amount of water is equal to $53.5 \mathrm{wt} \%$ of the waste solution. Actual caustic salt waste as shown in Table I can be represented by the formula

$$
7.11 \mathrm{NaOH} \cdot 27.5 \mathrm{H}_{2} \mathrm{O}+2.05 \mathrm{NaNO}_{3}+1.11 \mathrm{NaNO}_{2}
$$

if it is assumed that $\mathrm{NaAlO}_{2}$ is capable of reacting with phosphoric acid in a manner similar to NaOH. The 7.11 moles of available sodium are the difference between total sodium molarity and the molarity of nitrate plus nitrite $[10.28-(2.06+1.11)]$.

By using the ratio of 1 mole phosphate to 3.12 moles of available sodium, 2.28 moles of phosphate react with the 7.11 moles of available sodium. The reaction is shown in formula (5).

$7.11 \mathrm{NaOH} \cdot 27.5 \mathrm{H}_{2} \mathrm{O}+2.06 \mathrm{NaNO}_{3}+1.11 \mathrm{NaNO}_{2}+2.28\left(\mathrm{H}_{3} \mathrm{PO}_{4} \cdot 0.96 \mathrm{H}_{2} \mathrm{O}\right) \rightarrow$ $2.28\left(\mathrm{Na}_{3} \mathrm{PO}_{4} \cdot 12 \mathrm{H}_{2} \mathrm{O}\right) \mathrm{NaOH}+7.52 \mathrm{H}_{2} \mathrm{O}+2.06 \mathrm{NaNO}_{3} \downarrow+1.11 \mathrm{NaNO}_{2} \downarrow$

Because of the high monobasic salt content, only about three-fourths of the water in formula (2) is tied up in the hydrated trisodium phosphate complex. However, the neutralization of 103-BY as shown in Figure 4 indicates that total solidification occurred.

This difference between experimental observations and 
theoretical mechanisms has to be explained as interstitial liquid retention by adhesion and Van der Waal's forces. Experiments show that commercial grade trisodium orthophosphate retains about 6 wto water when pressed under 28 psi static pressure.

\section{REFERENCES}

1. Cyril M. Slansky and James A. Buckham, "Ultimate Management of Radioactive Liquid Waste," Chemical Engineering Progress Symposium Series, vol. 65, Number 97, 1969.

2. J. O. Skolrud, Preliminary Report Neutralization of High Caustic ITS Recycle, ARH-2199, Atlantic Richfield Hanford Company, Richland, Washington, August 1971.

3. J. S. Buckingham, Interim Report II: Cooling and Nitric Acid Neutralization of Recycle salt waste supernatant Liquid, ARH-2414, Atlantic Richfield Hanford Company, March 1972 .

4. Russell N. Bell, "Hydrates of Trisodium Orthophosphates," Industrial and Engineering Chemistry, vol, 41, No. 12, December 1949.

5. Bernard Wendrow and Kenneth A. Kobe, "The System Sodium Oxide-Phosphorus Pentoxide-Water," Industrial and Engineering Chemistry, vol. 44, No. 6, June 1952. 


\section{DISTRIBUTION}

\section{Atlantic Richfield Hanford Company}

T. D. Anderson

G. S. Barney

G. L. Borsheim

J. S. Buckingham

M. H. Campbell (5)

C. A. Colvin

R. P. Corlew

J. B. Fecht

C. J. Francis

H. H. Hopkins, Jr.

R. E. Isaacson

H. F. Jensen

M. J. Kupfer

D. J. Larkin

P. D. Leavitt

C. A. Lorenzen

M. L. Madeen

W. P. Metz

G. C. Oberg

D. A. Puryear (20)

L. M. Richards

R. C. Roal

L. W. Roddy

W. H. Sant

W. C. Schmidt

V. I. Schuelein

W. W. Schulz

H. P. Shaw

J. O. Skolrud

A. E. Smith

P. W. Smith

R. E. Smith

C. P. Sutter

M. J. Szulinski

J. H. Warren

J. C. Womack

ARHCO Document Services 